\title{
RELATIONSHIP BETWEEN ANEMIA AND HEART DISEASE IN PATIENTS WITH RHEUMATOID ARTHRITIS
}

\section{L.I. FEYSKHANOVA ${ }^{1}$, E.V. SUKHORUKOVA², A.I. AKHMETZYANOVA ${ }^{1}$}

1 Department of Hospital Therapy, Kazan State Medical University, Kazan, Russian Federation

2 Department of Rheumatology, Republican Clinical Hospital, Kazan, Russian Federation

\begin{abstract}
Objective: To determine the impact of anemia on the structural-geometrical condition of the heart in patients with rheumatoid arthritis (RA). Methods: 154 patients with RA were included in the study: 37 patients with anemia ( $1^{\text {st }}$ group) and 117 - without systemic manifestations of RA ( $2^{\text {nd }}$ group). All patients underwent echocardiography.

Results: Both groups were comparable in age, sex, ratio of seropositive and seronegative patients. A comparative analysis of both groups revealed that in $1^{\text {st }}$ group DAS28 was higher than in $2^{\text {nd }}$ group $(p<0.05)$. The left ventricular myocardial mass index was higher in $1^{\text {st }}$ group than in the $2^{\text {nd }}$ group $(p<0.05)$. The same applies to the left ventricular end-diastolic diameter: in patients with anemia, it was more than in patients without it $(p<0.05)$. Our results suggest that patients with anemia often have a violation of diastolic myocardial function, which is accompanied by an increase in myocardial mass. The correlation analysis in both groups revealed a direct relationship between age and left ventricular mass index $(r=0.62, p<0.0005)$, inverse relationship between age and $\mathrm{E} / \mathrm{a}$ parameter of mitral valve $(\mathrm{r}=-0.71, \mathrm{p}<0.00001)$. In addition, in $1^{\text {st }}$ group we revealed the inverse relationship between DAS28 and E/a parameter of tricuspid valve $(r=-0.43, p<0.05)$.

Conclusions: Thus, regardless of the presence of anemia, the patients with RA observed dependence of structural and functional changes in the heart of age: a violation of diastolic function of the left ventricle, an increase of the left ventricular myocardial mass index. However, in patients with anemia, an increase in the activity of the disease is accompanied by diastolic dysfunction of the right ventricle that requires correction in patient management process.

Keywords: Rheumatoid arthritis, anemia, echocardiography, diastolic dysfunction.
\end{abstract}

For citation: Feyskhanova LI, Sukhorukova EV, Akhmetzyanova Al. Relationship between anemia and heart disease in patients with rheumatoid arthritis. Vestnik Avitsenny [Avicenna Bulletin]. 2019;21(3):432-5. Available from: https://doi.org/10.25005/2074-0581-2019-21-3-432-435.

\section{ВЗАИМОСВЯЗЬ МЕЖДУ АНЕМИЕЙ И ПОРАЖЕНИЕМ СЕРДЦА У ПАЦИЕНТОВ С РЕВМАТОИДНЫМ АРТРИТОМ}

\section{П.И. ФЕЙСХАНОВА', Е.В. СУХОРУКОВА², А.И. АХМЕТЗЯНОВА ${ }^{1}$}

1 Кафедра госпитальной терапии, Казанский государственный медицинский университет, Казань, Российская Федерация

2 Отделение ревматологии, Республиканская кдиническая больница, Казань, Российская Федерация

Цель: определить влияние анемии на структурно-геометрическое состояние сердца у пациентов с ревматоидным артритом (РА).

Материал и методы: в исследование были включены 154 пациента с PA: 37 больных с анемией (I группа) и 117 - без системных проявлений PA (II группа). Все пациентам проведена эхокардиография.

Результаты: обе группы были сопоставимы по возрасту, полу, соотношению серопозитивных и серонегативных пациентов. Сравнительный анализ обеих групп показал, что в I группе индекс DAS28 был выше, чем во II группе (p<0,05). Индекс массы миокарда левого желудочка был выше в I группе по сравнению со II ( $<<0,05)$. То же касалось и конечного диастолического размера левого желудочка: у пациентов с анемией он оказался больше, чем у пациентов без неё $(p<0,05)$. Наши результаты показали, что у пациентов с анемией часто наблюдается нарушение диастолической функции миокарда, которое сопровождается увеличением массы миокарда. Корреляционный анализ в обеих группах выявил прямую связь между возрастом и индексом массы левого желудочка $(r=0,62, p<0,0005)$, обратную связь между возрастом и показателем E/а митрального клапана $(r=-0,71, p<0,00001)$. Кроме того, в I группе мы выявили обратную зависимость между DAS28 и параметром E/a трикуспидального клапана $(r=-0,43, p<0,05)$.

Заключение: таким образом, независимо от наличия анемии, у пациентов с РА наблюдается зависимость структурных и функциональных изменений сердца от возраста: нарушение диастолической функции левого желудочка, увеличение индекса массы миокарда левого желудочка. Однако у пациентов с анемией увеличение активности заболевания сопровождается диастолической дисфункцией правого желудочка, что требует коррекции в тактике ведения пациента.

Ключевые слова: ревматоидный артрит, анемия, эхокардиография, диастолическая диссункция.

Для цитирования: Feyskhanova LI, Sukhorukova EV, Akhmetzyanova Al. Relationship between anemia and heart disease in patients with rheumatoid arthritis. Vestnik Avitsenny [Avicenna Bulletin]. 2019;21(3):432-5. Available from: https://doi.org/10.25005/2074-0581-2019-21-3-432-435

\section{INTRODUCTION}

Rheumatoid arthritis (RA) is a chronic disease characterized by damage of musculoskeletal system, and this disease is often accompanied by various systemic, extra-articular manifestations (EAM). Presence of EAM of RA occurs in more severe disease [1]. EAM of RA can occur at any age after onset [2]. And also, EAM of RA are still a major mortality risk factor for patients [3]. One of these manifestations is anemia. It is important to know hemoglobin level, because using this we can predict disease activity in RA patients which can guide us for proper management to prevent further disease progression [4].

The most common pathogenetic variant of anemia is anemia of chronic diseases, which can be considered as a systemic manifestation of RA, because it is a consequence of inflammatory process. The anemia of chronic disease (ACD) refers to the impaired 
production of erythrocytes associated with chronic inflammatory status, including autoimmune diseases $[5,6]$. The actions of several pro- and anti-inflammatory cytokines and hormones produce the suppression of erythropoiesis [7]. This problem is topical, because anemia can independently impact on morbidity and mortality in patients with conditions associated with $A C D$ as well as affecting quality of life [8].

The second most common variant is iron deficiency anemia, which is widely spread in the world, regardless of the main disease. Aplastic anemia as a result of depression of blood formation when patient uses cytostatic therapy and megaloblastic anemia as a result of vitamin B12 deficiency and/or folic acid deficiency are less common [9].

It is known that patients with RA have a higher risk of coronary heart disease and sudden cardiac death [10-12]. Chronic inflammation plays a pivotal role in this increased risk [11]. Some authors associate it with the heart failure (HF), however, the real reason of myocardial dysfunction leading to HF in RA described in a few publications [13-15]. RA is associated with increased LV mass [3]. The nature of impairments in left ventricular (LV) function is complex, pathologic LV remodeling in patients with RA may contribute to impaired LV filling, resulting in the subsequent progression of myocardial dysfunction and the ultimate development of HF [11].

The relevance of the study is that in the literature there is a few information regarding the effects of anemia $[17,18]$ and rheumatoid arthritis $[11,19]$ on structural-geometric condition of the myocardium, but there is no data about effects of anemia and RA together on the structural-geometric remodeling of myocardium.

The aim of our research was to determine the effect of anemia on the structural-geometric condition of the heart in patients with rheumatoid arthritis.

\section{MATERIALS AND METHODS}

154 patients suffering from RA involved in our research. 37 people were diagnosed with mild or moderate anemia ( $1^{\text {st }}$ group), and 117 people did not have systemic manifestations of RA ( $2^{\text {nd }}$ group). The diagnostic criterion for anemia was a decrease of hemoglobin concentration in the blood to less than $130 \mathrm{~g} / \mathrm{l}$ in men and less than $120 \mathrm{~g} / \mathrm{l}$ in women.

Inclusion criteria were:

- Patients have $1^{\text {st }}$ degree of arterial hypertension, lasting less than 1 year, or they have not arterial hypertension.

- In the history-cases there are no data on the presence of diseases that could lead to anemia.

- Patients have not coronary artery disease, heart valve defects and other diseases that could lead to structural- geometric remodeling of the myocardium except anemia and rheumatoid arthritis in their history-cases.

- The group of patients with anemia included only persons with $1^{\text {st }}$ degree of anemia $(\mathrm{Hb} \geq 91 \mathrm{~g} / \mathrm{l})$.

- Patients have not extraarticular manifestations of rheumatoid arthritis except anemia.

- Patients with curtain duration of rheumatoid arthritis from 5 to 6 years.

RA activity was assessed by the disease activity index DAS28. In addition to routine laboratory tests, all patients had blood test to determine the level of circulating immune complexes $(\mathrm{CIC})$ and antiMCV (antibodies to modified citrullinated vimentin) in serum, as well as echocardiography.

It is known that RA is characterized by presence of antibodies, including rheumatoid factor, antibodies to cyclic citrullinated peptide (ACCP) and anti-MCV. The specificity of the analysis for anti-MCV is about $98 \%$. In RA, it is comparable to the specificity of ACCP test (specificity is about $92-98 \%$ ) and much higher than specificity of rheumatoid factor (specificity of $70 \%$ ). Due to this advantage, this analysis was included in the diagnostic criteria of RA in 2010 [17].

Using the echocardiography, we performed standard examinations of the left ventricular mass index (LVMI), the relative wall thickness of the left ventricle (RWT), the Simpson ejection fraction (EF), left ventricular end-diastolic diameter (LVED), E/a parameters of mitral and tricuspid valves, where $E / a$ is the ratio of the speeds of early and late filling of the ventricles.

Statistical analysis was performed with "Statistica 10.0 for Windows". Taking into account differences of the data distribution from the normal distribution, the non-parametric Mann-Whitney $U$ test, and also Spearman's rank correlation and Fisher's exact test were used to compare the parameters of the studied groups. Differences were considered significant at a value of $p<0.05$. Descriptive characteristics are given as medians, 25 and 75 percentiles.

\section{RESULTS AND DISCUSSION}

Characteristics of patients are presented in Table 1 . Both groups were comparable in terms of age, sex, ratio of seropositive and seronegative patients. However, in comparing the percentage of people with different radiological stages of the disease, it turned out that patients with 3-4 stages $(p<0.05)$ predominate in the $1^{\text {st }}$ group.

In the comparative analysis of both groups, it was found that in the $1^{\text {st }}$ group level of disease activity, determined by DAS28, was higher than in the $2^{\text {nd }}$ group $(p<0.05)$. According to the results of echocardiography, the LVMI was higher in the $1^{\text {st }}$ group than in the group without systemic manifestations of RA $(p<0.05)$. The same applies to the LVED: in patients with anemia, it was higher than in patients without it $(p<0.05)$ (Table 2$)$.

Table 1 Characteristics of the groups of patients with anemia and without systemic manifestations of RA

\begin{tabular}{|c|c|c|}
\hline Patients with RA & With anemia & $\begin{array}{c}\text { Without systemic } \\
\text { manifestations }\end{array}$ \\
\hline Age (years) & $54[45 ; 62]$ & $54[47 ; 59]$ \\
\hline Gender, female/male (\%) & $91.9 / 8.1$ & $81.2 / 18.8$ \\
\hline Seropositivity +/- (\%) & $81.8 / 18.2$ & $77.8 / 22.2$ \\
X-ray stages of RA (\%) & 0 & 0 \\
1 & 16.2 & 33.4 \\
2 & 37.8 & 33.3 \\
\hline
\end{tabular}


Table 2 Levels of DAS28 index, CIC, anti-MCV and parameters of echocardiography in patients with anemia and without systemic manifestations of $R A$

\begin{tabular}{|c|c|c|}
\hline Patients with RA & With anemia & Without systemic manifestations \\
\hline DAS28 & $5.88[5.12 ; 6.5]^{*}$ & $5.4[4.84 ; 5.71]^{*}$ \\
\hline CIC & $121[93 ; 257]$ & $167.5[109.5 ; 196]$ \\
\hline anti-MCV & $3561.9[359.3 ; 7000]$ & $671.4[167.3 ; 6000]$ \\
\hline LVMI & $105[90 ; 122]^{*}$ & $89.4[79 ; 107.2]^{*}$ \\
\hline RWT & $0.37[0.35 ; 0.41]$ & $0.37[0.34 ; 0.43]$ \\
\hline E/a parameter of mitral valve & $1.085[0.75 ; 1.25]$ & $0.87[0.72 ; 1.25]$ \\
\hline E/a parameter of tricuspid valve & $1.31[1.17 ; 1.41]$ & $1.21[1.03 ; 1.36]$ \\
\hline LVED & $4.8[4.4 ; 5.15]^{*}$ & $4.5[4.2 ; 4.85]^{*}$ \\
$*-p<0.05$ & $66[62 ; 68]$ & $66[63 ; 68]$
\end{tabular}

Our results evidence that anemia is more common in patients with late (third to fourth) X-ray stages of RA and is accompanied by increase in the activity of the main disease. According to the results of echocardiography, it is important to notice that in patients with anemia a violation of the diastolic function of the myocardium, which is accompanied by an increase in myocardial mass, is more often.

In correlation analysis in the $1^{\text {st }}$ group we found a direct correlation between age and the LVMI ( $r=0.62, p<0.0005)$, between age and the LVED $(r=0.37, p<0.05)$. We also found a negative correlation between age and E/a parameter of mitral valve ( $r=-0.71$, $p<0.00001)$, between DAS28 index and E/a parameter of tricuspid valve $(r=-0.43, p<0.05)$, between anti-MCV level and the $E / a$ parameter of mitral valve $(r=-0.9, p<0.05)$.

In the group of patients without systemic manifestations, we found a direct correlation between age and LVMI $(r=0.46, p<0.0001)$, between age and relative wall thickness $(r=0.43, p<0.0005)$, and also the negative correlation between age and $E / a$ parameters of the mitral and tricuspid valves $(r=-0.55, p<0.00001 ; r=-0.27, p<0.05$ respectively).
The results of the correlation analysis indicated that, regardless of the anemia presence in patients with RA, the structural-geometric changes of the heart depend on age: LVMI is increased, and the diastolic function of the left ventricle is impaired. At the same time, in patients with anemia, increase of the activity of RA entails a worsening in the diastolic function of the right ventricle, and increase of anti-MCV level correlates with diastolic dysfunction of the left ventricle.

In many studies, it has been found that anemia take part in remodeling of the left part of the heart $[20,21]$, the same results have researches on RA [22-24]. However, in our research, we found that combination of anemia and RA leads to remodeling of the right part of the heart, which has big practical importance in clinical management of patients.

We conclude that increase of the disease activity in patients with RA and anemia evidenced a tendency to worsen diastolic myocardial dysfunction, what is more not only of the left ventricle, but also of the right ventricle. Thereby, in this group of patients it is advisable to control the activity of the disease more strictly, using the whole arsenal of modern medicaments, and the frequency of echocardiography to monitor myocardium condition.

\section{REFERENCES}

1. Mercado U, Barbosa B. Manifestaciones extraarticulares de artritis reumatoide. Med Int Mex. 2016;32(6):607-11.

2. Cojocaru M, Cojocaru IM, Silosi I, Vrabie CD, Tanasescu R. Extra-articular manifestations in rheumatoid arthritis. A Journal of Clinical Medicine. 2010;5(4):286-91.

3. Bonfiglioli KR, Carriço H, Mota L, Vargas-Santos AB, Albuquerque C, Giorgi R, et al. Extra-articular manifestations in rheumatoid arthritis: a comprehensive analysis in a large cohort. Annals of the Rheumatic Diseases. 2018;77:301.

4. Talukdar M, Barui G, Adhikari A, Karmakar R, Ghosh UC, Das TK. Heamatological parameters and disease activity in rheumatoid arthritis. Journal of Clinical and Diagnostic Research. 2017;11(1):EC01-EC04.

5. Fraenkel PG. Understanding anemia of chronic disease. American Society of Hematology. 2015;1:14-8.

6. Poggiali E, De Amicis MM, Motta I. Anemia of chronic disease: A unique defect of iron recycling for many different chronic diseases. European Journal of Internal Medicine. 2014;25:12-7.

7. Madu AJ, Ughasoro MD. Anaemia of chronic disease: an in-depth review. Med Princ Pract. 2017;26:1-9.

8. Cullis J. Anaemia of chronic disease. Clinical Medicine. 2013;13(2):193-6.

9. Möller B, Scherer A, Förger F, Villiger P, Finckh A. Anaemia may add information to standardized disease activity assessment to predict radiographic

damage in rheumatoid arthritis: a prospective cohort study. Ann Rheum Dis. 2014;73(4):691-6.

10. Pascale V, Finelli R, Giannotti R, Coscioni E, Izzo R, Rozza F, et al. Cardiac eccentric remodeling in patients with rheumatoid arthritis. Scientific Reports. 2018;8:5867. Available from: https://doi.org/10.1038/s41598-018-24323-0.

11. Myasoedova E, Davis JM III, Crowson CS, Roger VL, Karon BL, Borgeson DD, et al. Rheumatoid arthritis is associated with left ventricular concentric remodeling: results of a population-based cross-sectional study. Arthritis \& Rheumatism. 2013;65(7):1713-8. Available from: https://doi.org/10.1002/ art.37949.

12. Erhayiem B, Bissell L-A, McDiarmid AK, Swoboda PP, Kidambi A, Ripley DP, et al. Abnormal left ventricular geometry is prevalent in asymptomatic patients with established rheumatoid arthritis compared with those with early disease and healthy controls. Journal of Cardiovascular Magnetic Resonance. 2015;17(Suppl 1):297.

13. Kobayashi H, Hirano M, Yoneyama K, Nakajima Y. Left ventricular morphology and function in rheumatoid arthritis patients without cardiac symptoms, using a cardiac magnetic resonance imaging. Journal of Cardiovascular Magnetic Resonance. 2015;17(Suppl 1): 378.

14. Giles JT, Malayeri AA, Fernandes V, Post W, Blumenthal RS, Bluemke D, et al. Left ventricular structure and function in patients with rheumatoid arthritis, 
as assessed by cardiac magnetic resonance imaging. Arthritis \& Rheumatism. 2010;62(4):940-51. Available from: https://doi.org/10.1002/art.27349.

15. Khalid U, Egeberg A, Ahlehoff O, Lane D, Gislason GH, Lip GYH, Hansen PR. Incident heart failure in patients with rheumatoid arthritis: a nationwide cohort study. Journal of the American Heart Association. 2018;7:e007227. Available from: https://doi.org/10.1161/JAHA.117.007227.

16. Kuna AT. Mutated citrullinated vimentin antibodies in rheumatoid arthritis. Clin Chim Acta. 2012;413(1-2):66-73.

17. Kopylov FY, Shekochikhin DY. Anemia in cardiology practice. Difficult Patient. 2011;9(4):16-22.

18. Murkamilov IT, Ayipova DA, Ibragimov AA, Usupbaev DA, Kaliev R. Effects of renal anemia on heart restructuring processes in chronic glomerulonephritis. Cardiovascular Therapy and Prevention. 2016;15(5):74-8.

19. Polyakova SA, Ruskin TA. Structural and functional state of the left ventricular myocardium in women of reproductive age with rheumatoid arthritis. Modern Rheumatology. 2013;1:41-6.
20. Goncharova EV, Govorin AV, Chistyakova MV. Features of the formation of anemic cardiomyopathy in patients with chronic iron deficiency anemia in the Zaibaikal region. Far-Eastern Medical Journal. 2014;1:10-4.

21. Vertkin AL, Khovasova NO, Laryushkina ED, Shamaeva KI. Patient with anemia at outpatient admission. Cardiovascular Therapy and Prevention. 2014;13(3):67-77.

22. Anichkov DA, Shostak NA, Ivanov DS. Left ventricular hypertrophy in patients with rheumatoid arthritis. Rheumatology Science and Practice. 2005;43(3):29.

23. Jukova NV. The prevalence of concomitant diseases among in-patients on the subject of rheumatic gout. Problems of Social Hygiene, Public Health and History of Medicine. 2010;2:19-21.

24. Arshin EV, Tuev AV, Shchekotov VV. Left ventricular remodeling and diastolic function in patients with arterial hypertension and rheumatoid arthritis. Russian Journal of Cardiology. 2005;3:32-7.

\section{(i) author information}

Feyskhanova Lyutsiya Iskhakovna, Candidate of Medical Sciences, Associate Professor of the Department of Hospital Therapy, Kazan State Medical University

ORCID ID: 0000-0001-7830-5283

Sukhorukova Elena Vasilievna, Doctor, Department of Rheumatology, Republican Clinical Hospital ORCID ID :0000-0001-6274-4636

Akhmetzyanova Aygul Ildarovna, student of Kazan State Medical University ORCID ID: 0000-0003-2724-5115

Information about the source of support in the form of grants, equipment, and drugs

The authors did not receive financial support from manufacturers of medicines and medical equipment.

Conflicts of interest: The authors have no conflicts of interest.

\section{ADDRESS FOR CORRESPONDENCE:}

Feyskhanova Lyutsiya Iskhakovna

Candidate of Medical Sciences, Associate Professor of the Department of Hospital Therapy, Kazan State Medical University

420012, Russian Federation, Kazan, Butlerova str, 49

Tel.: +7 (917) 2752166

E-mail: ljuts@rambler.ru

\section{AUTHOR CONTRIBUTIONS}

Conception and design: FLI

Data collection: SEV, AA

Statistical analysis: SEV

Analysis and interpretation: FLI, SEV

Writing the article: FLI, AAI

Critical revision of the article: FLI, AAI

Overall responsibility: FLI

Submitted $\quad 06.03 .2019$

Accepted $\quad 26.09 .2019$

\section{СВЕДЕНИЯ ОБ АВТОРАХ}

Фейсханова Люция Исхаковна, кандидат медицинских наук, доцент кафедры госпитальной терапии, Казанский государственный медицинский университет

ORCID ID: 0000-0001-7830-5283

Сухорукова Елена Васильевна, врач ревматологического отделения, Ре спубликанская клиническая больница ORCID ID: 0000-0001-6274-4636

Ахметзянова Айгуль Илдаровна, студентка, Казанский государственный медицинский университет ORCID ID: 0000-0003-2724-5115

Информация об источнике поддержки в виде грантов, оборудования, лекарственных препаратов

Финансовой поддержки со стороны компаний-производителей лекарственных препаратов и медицинского оборудования авторы не получали.

Конфликт интересов: отсутствует.

\section{АДРЕС ДЛЯ КОРРЕСПОНДЕНЦИИ:}

\section{Фейсханова Люция Исхаковна}

кандидат медицинских наук, доцент кафедры госпитальной терапии, Казанский государственный медицинский университет

420012, Российская Федерация, г. Казань, ул. Бутлерова, 49

Тел.: +7 (917) 2752166

E-mail: ljuts@rambler.ru

\section{ВКЛАД АВТОРОВ}

Разработка концепции и дизайна исследования: ФЛИ

Сбор материала: СЕВ, ААИ

Статистическая обработка данных: CEB

Анализ полученных данных: ФЛИ, СЕВ

Подготовка текста: ФЛИ, ААИ

Редактирование: ФЛИ, ААИ

Общая ответственность: ФЛИ

$\begin{array}{ll}\text { Поступила } & 06.03 .2019 \\ \text { Принята в печать } & 26.09 .2019\end{array}$

